\title{
Effect of Different Nitrogen and Weeding Levels on Yield of Five Maize cultivars under Irrigation
}

\author{
Izzeldein Adam Mohammed Radma ${ }^{1, *}$, Yassin Mohammed Ibrahim Dagash ${ }^{2}$ \\ ${ }^{1}$ Ministry of Agriculture and Natural Resources, Gezira State, Sudan \\ ${ }^{2}$ College of Agricultural Studies, Sudan University of Science and Technology, Shambat, Sudan \\ *Corresponding Author: izzeldienadammohmmed@gmail.com
}

Copyright $@ 2013$ Horizon Research Publishing All rights reserved.

\begin{abstract}
Field experiments were conducted in the Demonstration Farm of Mohammed Osman Salih ( Blue Nile North of Gezira state / ElBagir area) for the two consecutive seasons ( summer $2007 / 2008$ and $2008 / 2009$ ) to study the effect of nitrogen and weeding levels on yield of five cultivars of maize (Zea Mays L.) under irrigation. The treatments used consisted of three levels of nitrogen control $\left(\mathrm{N}_{0}\right), 86 \mathrm{~kg} \mathrm{~N} / \mathrm{ha}\left(\mathrm{N}_{1}\right), 129 \mathrm{~kg} \mathrm{~N} / \mathrm{ha}\left(\mathrm{N}_{2}\right)$, two levels of weeding non-weed control $\left(\mathrm{W}_{0}\right)$, weeding $\left(\mathrm{W}_{1}\right)$ and five cultivars, open pollinated Giza-2 $\left(\mathrm{V}_{1}\right)$, Var-113 $\left(\mathrm{V}_{2}\right)$, Hudiba-1 $\left(\mathrm{V}_{3}\right)$ and Hybrid cultivars, Hycorn-90 $\left(\mathrm{V}_{4}\right)$ and Hycorn-675 $\left(\mathrm{V}_{5}\right)$.The 30 factorial treatments were executed in randomized complete block design, with four replications. The results obtained showed that nitrogen fertilizer had a significant effect on final seed yield and some yield components as cob yield and number of seeds per cob when different nitrogen doing with no-weeding was not significant for seed yield. The results from these experiments showed that hybrid cultivars maize efficiently utilized nitrogen without weeding better than the open cultivars except Giza-2.The results obtained showed negligible differences between the two seasons for yield. This justifies growing maize in summer with $129 \mathrm{~kg} / \mathrm{ha}$ nitrogen and good cultivation.
\end{abstract}

Keywords Cultivar, Irrigation, Nitrogen, Yield, Weeding.

\section{Introduction}

Maize or corn as a world crop is grown in various countries. The crop is widely used as a food crop in many parts of the world especially in the tropical and subtropical countries. Maize is rich in starch (carbohydrates) with an average of about $70 \%$, but low in protein (about $9.5 \%$ ). The oil is concentrated mainly in the germ with an average of $4 \%$ of the kernel weight. The compositions of the other components of the kernel are $1.4 \%$ sugars, 2.3 crude fibre and $1.4 \%$ ash.
Maize grain enters also in livestock feeds, and in other industrial purposes as in the case of glucose and starch and edible oil industries.

In industrialized countries, maize is largely used as livestock feed and as a raw material for industrial products, while in developing courtiers it is mainly used for human consumption. In sub-Saharan Africa, maize is a staple food for $50 \%$ of the population. It is important source of carbohydrate, protein, vitamin B, and minerals. Green maize (fresh on the cob) is eaten boiled, playing an important role in filling the hunger gap CIMMYT[1]

Maize (Zea mays L,) is grown on approximately 140 million hectares $(\mathrm{M} / \mathrm{ha})$ worldwide: $97 \mathrm{M} / \mathrm{ha}$ in developing countries, $34 \mathrm{M} / \mathrm{ha}$ in the high income countries, and $9 \mathrm{M} / \mathrm{ha}$ in the Eastern Europe and the former Soviet Union http://www.c[2]

Maize is a staple food for several hundred million people in the developing world. The average inhabitant of Eastern and Southern Africa consumes about $80 \mathrm{~kg}$ of maize each year; while in Mexico, Central America, and the Caribbean he consumes about $170 \mathrm{~kg}$. Annual per capita maize utilization averages $100 \mathrm{~kg}$ in East Asia and more than $190 \mathrm{~kg}$ in the southern cone of South America, largely as animals feed in both cases. Unfortunately, developing countries do not produce enough maize to meet their needs and must therefore import approximately 30 million tons of maize annually. Use of improved cultivars and management practices should help increase maize yield and reduce imports in developing countries. \{(http:// www[3]

Maize is the second most important crop of New World food programme (Anonymous[4] In New World food programme, maize is grown on 539,215 ha with a total production of 836,446 tons and per ha yield of $1551 \mathrm{~kg}$. It serves as a food, fodder and feed and also as a source of raw material for the industry. Average yield of maize in Pakistan and New World food programme is very low as compared to other maize growing countries of the world .

The weed control is an important management practice for maize production and should be carried out to ensure optimum grain yield. Weed control in maize is carried out by mechanical and/ or chemical methods. Weed between plants 
rows are removed generally by mechanical cultivation. While weeds on the rows are controlled by hand hoeing or by herbicides, and both methods are effective in controlling weeds.

The average annual harvested area in the world is over 150 million hectares with seed production of about 800 million metric tons with an average yield of 4970.9 kilogram per hectares Wikipedia[5] The average harvested area in the world is about 130 million hectares with seed production of about 455 million metric tons per hectare Ali[6] The United States exports about 59 per cent of the world trade of corn. Other maize exporting countries include: China, Brazil, Mexico, Argentina, India and France.

The leading importing countries include: Italy, Japan, United Kingdom, Germany, Netherlands and Spain Jugenheimer[7]. In Africa, the Portuguese brought maize from the West Indies to the island of Sao Tome, and from there it was taken to the Cold Coast. Apparently, it reached South Africa shortly after the arrival of the first Dutch colonists, where it now occupies $65 \%$ of the land under cropping, and it is the main staple food of the majority of the people. Another possibility is that the crop may have entered Africa through Egypt, where maize cultivation was established in the latter half of the eighteenth century with cultivars imported from Syria and India Song et al[8].

In Sudan, Maize utilization as a human food for making bread was limited, where most of the produce is consumed as roasted kernels or in mixing with wheat to make bread. The environmental conditions in the Sudan are generally favorable for maize production. Old statistics showed that the crop used to be produced in various ecological zones $\operatorname{Arab}[9]$ and $\mathrm{AOAD}[10]$.

The total area of maize was 160 hectares in 1999 and the total production was $406 \mathrm{~kg}$ tha Lower yields and low market prices, were the main factors, which gave low priority for maize in agricultural development in the Sudan .Results indicated the success of the crop under rain-fed conditions where an average yield of about 1.9 tonlfeddan was obtained. Further experimental trials were carried out by the Arab African Company for Agricultural and Industrial Development under irrigation (3.000 feddans) in Gezira FAO[11].

As mentioned before, the yield of maize per unit area in the Sudan is the very low compared to the world average. The reasons are many including management and the main objective of this research is to study the effects of the nitrogen and weeding on productivity of a number of maize genotypes and to select the best cultivar for the prevailing conditions.

\section{Materials and Methods}

The experiment was conducted for two consecutive summer seasons of 2007/2008 and 2008/2009.

The objectives of this experimental were to investigate the effect of nitrogen and weeding levels on yield of five maize (Zea mays) cultivars .
For the security reasons and the reliability of the result they were conducted in the farms of Osman Salih ElBagir area (North of Gezira state. Sudan) latitude 15-22N and longitude 32-46 E.

Prior to commencement of the experiment, soil samples were taken for the analysis of soil, which showed that soil was sandy clay loam with a $\mathrm{pH}$ range from $8.29-8.88$. It was found that the sand content ranged from 38.80 to $69.80 \%$, the silt content from $4.44-28.00 \%$ and the clay contents from 24.48 to $33.20 \%$. The nitrogen content was found to be $0.0079-8.035 \%$ and $0.0079-0.047 \%$ over dry weight. The phosphorus content $0.55-1.85 \mathrm{mg} / \mathrm{L}$ and the $\mathrm{K}$ contents was 0.200 to $0.92 \mathrm{mg} / \mathrm{L}$.

The climate of the locality is tropical semi-arid with low relative humidity. During summer in the first season, the range of temperature was $41.6-19.5^{\circ} \mathrm{C}$ and during the second season it was $42.6-19.2^{\circ} \mathrm{C}$. Temperature, relative humidity and rainfall data for the two seasons was obtained from Ministry of Sciences and Technology, Meteorological Authority, Khartoum Station .

The seeds of open-pollinated cultivars (Geza-2, Hudeiba-1 and var-113) were obtained from the Seed Propagation Administration, Gezira Research Station. The 2 hybrid cultivars (Hycorn-90 and Hycorn-675) were obtained from Pacific Seeds PTY .LTD.

The experiment was factorial in a randomized complete block design, with four replications. The treatments consisted of the five cultivars of maize $\left(\mathrm{V}_{1}=\right.$ Geza-2, $\mathrm{V}_{2}=$ var-113, $\mathrm{V}_{3}=$ Hudiba $-1, \mathrm{~V}_{4}=$ Hycorn- $90, \mathrm{~V}_{5}=$ Hycorn- 675 . The three levels of nitrogen are:-

$\mathrm{N}_{0}=\left(\right.$ control ) with no nitrogen, $\mathrm{N}_{1}(86 \mathrm{~kg} \mathrm{~N} / \mathrm{ha}), \mathrm{N}_{2}$ $(129 \mathrm{~kg} \mathrm{~N} / \mathrm{ha})$ : and the two levels of weed are : $\mathrm{W}_{0}$ ( control ) with no weed, $\mathrm{W}_{1}=$ weeding .

Before sowing the fertilizer was applied where nitrogen was broad-cast on top of the ridges. Sowing was done by hand where $2-3$ seeds per hole were sown on top of the ridge in holes $20 \mathrm{~cm}$ within the ridge, then the seedings were thinned to one plant per hole .The experiment was sown on the $27^{\text {th }}$ of July in the first season $(2007 / 2008)$ and on the $1^{\text {st }}$ of August (2008/2009).

The watering interval was $8-10$ days in both season and the plants were thinned to one plant per hole after seventeen days from planting. More than three manual weedings in each seasons were carried out according to the block design treatments.Termites infestation was observed when the crop was 35 days old in the two seasons. The crop was sprayed with Dursban $10 \mathrm{ml} / \mathrm{L}$ in first season and in the second season the crop sprayed with Morsban $(480 \mathrm{ml} / \mathrm{L})$.

The number of cobs per plant was taken at 60 and 75 days from sowing, for each of the six plants per plot.

The six plants of each plot were cut at 120 days from sowing and sun-dried then weighed and the average dry weight per plant was recorded.

When signs of maturity were clear on the plants (complete yellowing of leaves and cobs and partial shedding of leaves), harvesting was made for the remaining plants for the plot to estimate the final yield. 
The cobs of six plants in each plot were measured and the average cob length was recorded for each plot.

The average number of seeds per cob and the average weight per cob were also made.

100 -seeds were counted randomly and weighed for each plot.

The cobs from each plot of the harvested plants were weighed then threshed and the seed yields for each plot were recorded. Yield per hectare was then estimated.

Data collected from the different treatment were subjected to analysis of variance (ANOVA) appropriate for randomized complete block design (Gomez and Gomez, 1984). The means were separated using the least significant difference (LSD) and Duncan Multiple Range Test (DMRT).

\section{Results}

Analysis of variance(table 1,2) show clear significant $(\mathrm{P}=$ 0.01 ) differences in dry weight between the levels of nitrogen. The application of $86 \mathrm{~kg} \mathrm{~N} /$ ha gave $20 \%, 26 \%$ significantly higher dry weight over control, whereas the application of $129 \mathrm{~kg} \mathrm{~N} /$ ha increased the dry weight per plant over the control by $27 \%, 30 \%$ respectively. Also, in the two season there were significant $(\mathrm{P}=0.01)$ differences between cultivars, where cultivar HyCorn-90 gave significantly higher dry weight than the cultivars Giza-2, var.113, Hudiba-1 and Hycorn-675, which were significantly different from each other. The interaction between treatments and weeding were also significant .

Table 1. F-value of the measured variables for interaction of cultivar weeding and fertilizer treatment

\begin{tabular}{|c|c|c|c|c|c|c|c|c|}
\hline \multicolumn{9}{|c|}{$2007 / 08$ season } \\
\hline $\begin{array}{l}\text { Source of } \\
\text { variation }\end{array}$ & d. $\mathrm{f}$ & $\begin{array}{l}\text { No .of } \\
\text { rows/cob }\end{array}$ & $\begin{array}{l}\text { Dry weight/plant } \\
\mathrm{g}\end{array}$ & $\begin{array}{l}\text { Weight of } \\
\text { seeds/cob }\end{array}$ & $\begin{array}{c}\text { 100-seeds } \\
\text { wt (g) }\end{array}$ & $\begin{array}{c}\text { No .of } \\
\text { seeds/cob }\end{array}$ & $\begin{array}{c}\text { Length of } \\
\text { cob } \\
(\mathrm{cm})\end{array}$ & $\begin{array}{c}\text { Yield of seeds } \\
\mathrm{kg} / \mathrm{ha}\end{array}$ \\
\hline $\mathrm{V}$ & 4 & $6.68 *$ & $36.28 * *$ & $61.62 * *$ & $16.55 *$ & $110.8 * *$ & $35.18 * *$ & $41.254 * *$ \\
\hline $\mathrm{N}$ & 1 & $0.505 \mathrm{NS}$ & $656.7 * *$ & $376.5 * *$ & $267.1 * *$ & $182.6 * *$ & $94.05 * *$ & $214.634 * *$ \\
\hline W & 2 & $0.95 \mathrm{NS}$ & $117.6^{* *}$ & $1724 * *$ & $\begin{array}{c}499.64 * \\
*\end{array}$ & $61.30 * *$ & $3.81 \mathrm{NS}$ & $1.086 \mathrm{NS}$ \\
\hline $\mathrm{VN}$ & 4 & $5.38 *$ & $117.62 * *$ & $56.92 * *$ & $8.56^{*}$ & $6127 * *$ & $4.99 \mathrm{NS}$ & $39.55 * *$ \\
\hline VW & 8 & $4.22 * *$ & $27.98^{*}$ & $76.62 * *$ & $12.28 * *$ & $54.72 * *$ & $10.75^{*}$ & $48.48 *$ \\
\hline NW & 2 & $1.35 \mathrm{NS}$ & $20.84^{*}$ & $19.62 *$ & $\begin{array}{c}113.25 * \\
*\end{array}$ & $15.26^{* *}$ & $3.59 \mathrm{NS}$ & $10.352 *$ \\
\hline VNW & 8 & $3.09 *$ & $98.44^{* *}$ & $64.57 * *$ & $9.73^{*}$ & $29.84 * *$ & $5.315 *$ & 43.55 \\
\hline Ms. Error & & 1.056 & 43.93 & 7.114 & 2.325 & 564.11 & 1.05 & 82.061 \\
\hline SE & & 0.297 & 1.913 & 0.770 & 0.440 & 7.383 & 0.296 & 2.3 \\
\hline LSD & & 0.6162 & 4.195 & 1.693 & 0.9272 & 14.45 & 0.680 & 181.2 \\
\hline C.V \% & & $1.5 \%$ & $0.7 \%$ & $7.5 \%$ & $4.7 \%$ & $8.3 \%$ & $3.4 \%$ & $15.6 \%$ \\
\hline
\end{tabular}

$* *=$ significant at $1 \%$ level ( highly significant)

$*=$ significant at $5 \%$ level (significant)

$\mathrm{NS}=$ not significant

Table 2. F-value of the measured variables for interaction of cultivars weeding and fertilizer treatments

2008 / 2009 season

\begin{tabular}{|c|c|c|c|c|c|c|c|c|}
\hline $\begin{array}{l}\text { Source of } \\
\text { variation }\end{array}$ & d. $f$ & $\begin{array}{l}\text { No .of } \\
\text { rows } \\
\text { Per cob }\end{array}$ & $\begin{array}{c}\text { Dry weight per } \\
\text { plant } \\
\text { G }\end{array}$ & $\begin{array}{l}\text { Weight of } \\
\text { seeds/cob }\end{array}$ & $\begin{array}{c}100 \text { seeds } \\
\text { weight }(\mathrm{g})\end{array}$ & $\begin{array}{c}\text { No .of seeds } \\
\text { /cob }\end{array}$ & $\begin{array}{l}\text { Length of cob } \\
\qquad(\mathrm{cm})\end{array}$ & Yield of seeds $\mathrm{kg} / \mathrm{ha}$ \\
\hline $\mathrm{V}$ & 4 & $178.78 * *$ & $25.22 *$ & $20206.0 * *$ & $215.7 * *$ & $55.320 .3^{* *}$ & $2118.2 * *$ & $1641444.4 * *$ \\
\hline $\mathrm{N}$ & 2 & $93.07 *$ & $49.12 *$ & $26278.2 * *$ & $2495.01 * *$ & $73768.1 * *$ & $14759.0 * *$ & $113491135.8 * *$ \\
\hline $\mathrm{W}$ & 1 & $180.08 * *$ & $80.03 * *$ & $86887.0 * *$ & $1184.4 * *$ & $125001.1 * *$ & $8806.5^{* *}$ & $5441476.4 * *$ \\
\hline $\mathrm{VN}$ & 8 & $81.51 *$ & $6.38 *$ & $13632.1 * *$ & $171.23 * *$ & $121318.9 * *$ & $411.23 * *$ & $5540227.7 * *$ \\
\hline VW & 4 & 43.218 & $10.21 *$ & $8238.8^{* *}$ & $7163 *$ & $20859.2 * *$ & $388.38 * *$ & $448216.1 * *$ \\
\hline NW & 2 & $21.80^{*}$ & $2.11 \mathrm{NS}$ & $4386.2 * *$ & $447.3 * *$ & $42850.9 * *$ & $535.9 * *$ & $3740356.8 * *$ \\
\hline VNW & 8 & $45.28 * *$ & $19.88^{*}$ & $14665.7 * *$ & $202.26 * *$ & $31261.1^{* *}$ & $1185.71 * *$ & $7498855.9 * *$ \\
\hline Ms. Error & & 3.83 & 2.344 & 217.72 & 9.514 & 911.78 & 24.494 & 143923.7 \\
\hline SE & & 0.565 & 0.442 & 4.26 & 0.980 & 8.717 & 1.429 & 109.515 \\
\hline LSD & & 1.227 & 0.964 & 9.295 & 1822 & 19.15 & 3.143 & 239.3 \\
\hline C.V \% & & $13.3 \%$ & $36.4 \%$ & $26.8 \%$ & $31.3 \%$ & $35.9 \%$ & $35.6 \%$ & $39.3 \%$ \\
\hline
\end{tabular}

$* *=$ significant at $1 \%$ level ( highly significant)

$*=$ significant at $5 \%$ level (significant)

$\mathrm{NS}=$ not significant 
The application of $86 \mathrm{~kg} \mathrm{~N} / \mathrm{kg}$ did not increase rows number per cob compared to the control, whereas the application of $129 \mathrm{~kg} \mathrm{~N} /$ ha increased the number of rows per cob over control by $8 \%$ in the first season, however application of 86 and $129 \mathrm{~kg} \mathrm{~N} /$ ha gave similar significantly $9 \%$ higher number of rows per cob over the control in the second season. On other hand, there were no significant differences in the number of rows per cob between the application of 86 and $129 \mathrm{~kg} \mathrm{~N} /$ ha (Table1,2). Also, there were no significant differences between the five cultivars in number of rows per cob. The differences between the two levels of weeding and the interaction were not significant in the both.

From the statistical analysis(table1,2), it was clear that there were significant $(\mathrm{P}=0.01)$ differences in 100 -seeds weight between the levels of nitrogen. The application of 86 $\mathrm{kg} \mathrm{N} /$ ha gave $25 \%, 31 \%$ significantly higher 100 -seeds weight over the control, whereas the application of $129 \mathrm{~kg}$ $\mathrm{N} /$ ha increased the weight of seeds over the control by $69 \%$, $75 \%$ respectively. First season there were significant $(\mathrm{P}=$ 0.01) differences between cultivars, where cultivars Hycorn-90 and Hycorn-675 gave significantly higher 100 -seeds weight than the cultivars Giza-2, var-113 and Hudiba-1 which were not significantly different from each other. In second season also There were significant $(\mathrm{P}=0.01)$ differences between cultivars, where Hudiba-1 gave significantly higher weight of 100-seed than Giza-2, var-113, Hycorn-90 and Hycorn-675, which were also significantly different from each other. Weeding gave significant higher seed weight over the control and treatment interaction were significant in both.

From the analysis of variance (table1,2), it was clear that there were significant differences in length of cob between the levels of nitrogen. The application of $129 \mathrm{~kg} \mathrm{~N} /$ ha gave $8 \%, 23 \%$ significantly longer cobs than the control respectively, whereas in the first one the application of $86 \mathrm{~kg}$ $\mathrm{N} /$ ha did not increase the length of cobs over the control, there were no significant differences in the length of cob between the application of 86 and $129 \mathrm{~kg} \mathrm{~N} / \mathrm{ha}$, there were significant differences between the cultivars, where Hycorn-90, Hycorn-675 and Giza-2 gave significantly taller length than var-113 and Hudeiba-1. While the second season . the application of $86 \mathrm{~kg} \mathrm{~N} /$ ha gave $15 \%$ significantly longer cobs than the control and there were significant differences in the length of cobs between the application of 86 and 129 $\mathrm{kg} \mathrm{N} / \mathrm{ha}$, there were significant differences between cultivars, where cultivars Hycorn-90 and Hycorn-675 gave significantly taller length than the cultivars Giza-2, var-113 and Hudeiba-1 which were not significantly from each other. The differences between the two levels of weed, the weeding levels gave $15 \%, 23 \%$ significant over the control respectively.

Statistical analysis(table1,2) shows a significant effect of nitrogen and weeding and their interaction an seed weight per cob. The application of $86 \mathrm{~kg} / \mathrm{ha}$ gave $44 \%, 38 \%$ significantly heavier weight of seeds/cob over control, whereas the application of $129 \mathrm{~kg} \mathrm{~N} /$ ha increased the weight of seeds over the control by $106 \%, 84 \%$ respectively. On the other hand, there were significant differences in the weight of seeds between the application of 86 and $129 \mathrm{~kg} \mathrm{~N} / \mathrm{ha}$ in the both. Also, there were significant $(\mathrm{P}=0.01)$ differences between cultivars, in 2007/2008 Giza-2 gave significantly higher weight of seeds than var-113, Hudiba-1, Hycorn-90 and Hycorn-675, which were not significantly different from each other. While in 2008/2009 Hycorn-90 and Hycorn -675 gave significantly higher weight of seeds per cobs than Giza-2 ,var-113and Hudiba -1, which were also significantly different from each other. The difference between the two levels of weeding and interaction were significant.

From the statistical analysis (table1,2), it was clear that there were significant $(\mathrm{P}=0.01)$ differences in seeds number per cob between the levels of nitrogen. The application of 86 $\mathrm{kg} \mathrm{N} /$ ha gave $40 \%, 38 \%$ significantly higher number of seeds over the control, whereas the application of $129 \mathrm{~kg} \mathrm{~N} / \mathrm{ha}$ increased the number of seeds per cob over the control by $27 \%, 84 \%$ respectively. On the other hand, in the first season there were no significant differences in the number of seeds per cob between the application of 86 and $129 \mathrm{~kg} \mathrm{~N} / \mathrm{ha}$. Also, there was significant $(\mathrm{P}=0.01)$ difference between cultivars, where Giza-2 gave significantly higher number of seeds per cob than the cultivars var-113, Hudiba-1, Hycorn-90 and Hycorn-675.In the second season there were significant differences in the number of seeds per cob between 86 and $129 \mathrm{~kg} \mathrm{~N} / \mathrm{ha}$. Also, there was significant $(\mathrm{P}=0.01)$ difference between cultivars, where Hudiba-1 gave significantly higher number of seeds per cob than Giza-2, var-113, Hycorn-90 and Hycorn-675. Weeding gave significant increase in seed number over the control in both seasons.

There were significant $(\mathrm{P}=0.01)$ differences in seed yield per hectare between the levels of nitrogen. The application of $86 \mathrm{~kg} \mathrm{~N} /$ ha gave 49\%, 29\% significantly higher seed yield over the control, whereas the application of $129 \mathrm{~kg} \mathrm{~N} / \mathrm{ha}$ increased the seed yield over control by $106 \%, 86 \%$ respectively. On the other hand, there were significant differences in the seed yield between the application of 86 and $129 \mathrm{~kg} \mathrm{~N} /$ ha (Table 1,2). Also in the first season there were significant $(\mathrm{P}=0.01)$ differences between cultivars, whereas cultivar Giza-2 gave significantly higher seed yield than var-113, Hudiba-1, Hycorn-90 and Hycorn-675, which were significantly different from each other. season two cultivar Hudiba-1 gave significantly higher seed yield than the Giza-2, var-113, Hycorn-90 and Hycorn-675, which were significantly different from each other.

The weeding level gave significantly higher yield of seed $\mathrm{kg} / \mathrm{ha}$ over control. Treatment interaction was also significant.

\section{Discussion}

Weeding had significant effect on dry weight and in general weed control gave higher dry weight in both seasons. 
This result is confirmed by Teton-Kagho and Gardner[12]. Nitrogen application generally increased dry weight/plant and the increase reached significant levels at later stages of growth in both seasons. Such effects could be attributed to enhancement of vegetative growth and dry weight production by nitrogen. The interaction of $\mathrm{N}$ with weeding had significant effect on dry weight (at early stages at over 60 days from sowing) in the second season. It is well known that the combined effect of nitrogen and weeding is greater than individual effect of each treatment by itself.

Effects of nitrogen on number of seeds per cob are significant. Weed and the interaction of nitrogen were significant in both seasons. In this connection, Habib [13]; Sharma[14]; Lucas[15] found significant effects of nitrogen on number of seeds per cob. Singh et al[16] Gangwar and KaLm [17] and Cimmyt[18] found that maize yield and yield components were significantly increased by application of nitrogen.

The result obtained in both seasons showed no significant effect of nitrogen on 100-seeds weight, with significant effect of weeding. Ali [19] and Ologunde and Ogunlela [20] found no significant effects of nitrogen on 100-seeds weight. Weed removal had no-significant effect on number of rows/cob in both seasons, while weeding during different growth stages increased number of 100 -seeds weight. Oleson et al.,[21] studied the response of corn to weeding and reported both negative and positive responses. Positive responses were associated with low weed growth and negative responses with high weed growth during maize growth stages.

The effects of nitrogen, weed and their interactions on seeds yield were significant in both seasons. Sharma [22] found that nitrogen had significant effect on weight of seeds per plant. Gangwar and Kalm [23] stated that nitrogen significantly influenced yield attributes. Also cultivars showed significant difference seed yield. These results are in agreement with the results of Singh and Saroha [24]; Karama Swamy [25] ; Richards et al [26] and Omara[27] . On the other hand, increasing nitrogen, irrespective of weeding, gave a continuous increase in seeds yield. Similar results were obtained by Ali [28] and Arab O [29]. Ebaisary et al., [30] found significant increases in seed yield with increasing levels of nitrogen but the increase in seed yield above the levels of $80-130 \mathrm{~kg} \mathrm{~N} / \mathrm{ha}$ was low and not significant. On the other hand, Abdel Malik et al[31]; Okajima et al[32] and Affholder et al[33] found that seed yield increased significantly with the application of nitrogen and weed control.

In the present study in the two seasons, nitrogen gave a consistently, significant increase in yield and yield components. In this connection, Gardner et al[34] reported that various maize cultivars responded to the application of nitrogen up to $240 \mathrm{~kg} \mathrm{~N} / \mathrm{ha}$. The responses due to these high levels of nitrogen might be due to the poor soil conditions of the experimental site or due to high response of the cultivars used. In this study the highest number of seed/cob was obtained from plots kept weeded at early stage. Results from both seasons suggest that weed control should be carried out for maize to provide maximum grain yield per cob. Results obtained in this study in both seasons showed that the significant increase in seed yield and yield components were mainly due to the applications of nitrogen. The increase in seed yield can be attributed to the increase in cob yield and number of seeds per cob.

These increases were positively correlated with prolonged weed -free duration. However, yields obtained from plots kept weed-free until the growth of maize were not significant from those plot kept weed-free from emergence until row closure. This may be explained by the lower weed occurrence in maize until the 6-leaf stage. Hanway [35]; Berzensy et al[36] and Delpine and Covareli [37] stated that the nutrient uptake of maize from soil is relatively small during the 2-4 leaf stage of development.

In this study, grain yield of Hybrids and open pollinated cultivars of maize was positively affected by nitrogen and weeding significantly. In the first season, cultivar Giza-2 gave higher seed yield of $4.52 \mathrm{t} / \mathrm{ha}$, compared to other cultivars, but in the second season, cultivars Hycorn-90 and Hycorn-675 (Hybrid) gave higher grain yield of 4.10t/ha. Similar results were obtained by Adediran et al., [38]; FPDD [39]. The yield of hybrid maize increased with increase in nitrogen rate.

From the comparison of the seed yield in the two seasons, it was clear that there were very little differences between seasons, where in the first summer season seed yield varied between $2730-5631 \mathrm{~kg} / \mathrm{ha}$ with an average of $4.18 \mathrm{t} / \mathrm{ha}$ while the yield in the second season varied between 2.70 to5.03 t/ha with an average of $3.87 \mathrm{t} / \mathrm{ha}$.

\section{Conclusions}

In this study, $\mathrm{N}$ application to maize tended to improve seed yeild. The response to $\mathrm{N}$ increased as level of $\mathrm{N}$ applied increased. Thus it is feasible to recommend $\mathrm{N}$ application to maize under similar conditions .This suggest, as mentioned earlier, that maize crop in this area can successfully be grown in the summer season in Northern, Gezira and similar areas in Sudan.

The weed control used in this study failed to bring out clear differences in yield of maize. Also results of this experiment showed that weeds cause $42-62 \%$ yield losses in maize. However, a weed-free growth period during stages of the crop was enough to prevent these losses under similar growing conditions. These results are valuable for growers for developing an integrated weed control strategy.

The experiment was conducted during summer in both seasons. Further studies are needed to compare summer growing with winter growing.

The results from these experiments showed that hybrid maize (Hycorn-90 and Hycorn-675) efficiently utilized nitrogen better than the open pollinated (Hudiba-1andVar-113) with the exception of Giza-2. 


\section{REFERENCES}

[1] Cimmyt.Org1994Htt://Www./English/Docs/TechPubs/OpenPollinated/Devmainseed.html.

[2] Http://www.Cimmyt.org.(1994)./English/docs/tech-pups/ope n-pollination/devmainseed.htm.

[3] Http://www.bulbnrose(2009).org./Heredity/Anderson/Ander son maize Breeding.htm.

[4] Anonymous 2000. Agricultural Statistics Of Nwfp, Agricultural Statistics Wing, Agri: (Ext) Department, University Town, Peshawar.

[5] Wikipeda -2009 Htt://Www.Maize, The Free Encyclopedia.

[6] Ali , F.A (1996) .Maize Programme, Annual Report Agricultural Research Corporation .

[7] Jugenheimer, R.W.(1976). Corn Improvement Seed Production And Uses. Maximum Corn Production Depends On Many Factors. Pp. 11-23.Awiley Interscience Pub. Printed In The U.S.A.

[8] song.R.T and Messing, J.(2003) Gene expression of a gene family in maize based on noncollinear haplotypes. Proc.Natl.Acad.Sci. USA 100, 9055-9060 .[ PubMed] .

[9] Arab Organization For Agricultural Development (2006) .Study For Corn Production. Khrtoum.Sudan ( Arab Issue).

[10] Aoad-1986 Morocco Primary Feasibility Study For Corn Production At Gezira Province (Arabic Issue).

[11] FAO, (1980). Improvement And Production Of Maize, Sorghum And Millet. Vol.2.Breeding, Agron. And Seed Production.

[12] Tetio-Kagho, F. And Gardner, F.P (1988). Response Of Maize To Plant Population Density. I. Canopy Development, Light Relationships, And Vegetative. Agron. J.80:930-935.

[13] Habib, M.M.; Badr, M.F. and Solliman, S.M. (1971). Yield and quality of corn seed and stover as affected by early harvest and fertilizer levels. Alexandria J. Agric. Res., 19:245-251.

[14] Sharma, R.K (1973). Response Of Maize To Nitrogen Fertilization. Madras Agric.J.60 :399 -440.

[15] Lucas, E.O (1986). The Effect Of Density And Nitrogen Fertilizer On The Growth And Yield Of Maize (Zea May L) In Nigeria. J.Agric. Sci., 107:573 -578. In Soil and Fertilizer Abstr., 51, March 19988. Abstr.1931 .

[16] Singh, C.M., Sood, B.R.And Modgal, S.C. (1978). Response Of Rainted Pop Corn (Zea Mays Everta) To Nitrogen And Olant Population. Exp.Agric. 14:395 - 398.

[17] Gangwar, B. and Kalm, G.S. (1982). Intercropping of rainfed maize with different legumes, Ind. J. Agric., 52:133-116.

[18] Cimmyt.Org1994Htt:/Www./English/Docs/TechPubs/OpenPollinated/Devmainseed.html.

[19] Ali, F.M. (1994). Annual Report. Maize research program.
Agricultural Research Corporation, Ministry of Agriculture and Forestry, Sudan.

[20] Ologunde, O.O. and Ogunlela, V.B. (1984). Relationship of plant density and nitrogen fertilization to maize performance in the Southern Guinea Savanna of Nigeria. Samaru-J. of Agric. Res., 2:99-109. In soil and fertilizer Abst-51. March. 1988. 1934.

[21] Olson, R.A; Dreier, A.F; Hoover, C.A. And Rhoades, H. F. (1962) . Factors Responsible For Poor Response Of Corn And Grain Sorghum To Phosphorus Fertilization : I. Soil Phosphorus Level And Climatic Factors. Soil Sci.Soc. Amer. Proc.26:572-574.

[22] Sharma, R.K (1973). Response Of Maize To Nitrogen Fertilization. Madras Agric.J.60 :399 -440.

[23] Singh, H.G. and Saroha, M.S. (1970). Note on the time and method of urea application to maize (Zea mays L.) grown on soil with undulating topography. Indian J. Agric. Sci., 40(5):470-473.

[24] Gangwar, B. and Kalm, G.S. (1982). Intercropping of rainfed maize with different legumes, Ind. J. Agric., 52:133-116.

[25] Kamara swamy, R. (1973). A note on the availability of phosphorous with advancement of crop growth. Madras Agric. J. 60(5):341-342.

[26] Richards, J.E.; Shepperd, S.C. and Bates, T.E. (1983). Nitrogen fertilization of land continuously cropped to corn (Zea mays L.). Canadian J. Soil. Sci., 63(3):543-556.

[27] Omara, H.A. (1989). The effect of spacing, nitrogen and phosphorous application on growth and yield of maize (zea mays L.). M.Sc Thesis, Fac. of Agric. University of Khartoum, Sudan.

[28] Ebaisory, E.M.; ElDin, M.M.B and Negm, M.A. (1980). Studies on nitrogen nutrition of corn plant in calcareous soils. Effect of different nitrogen forms and rates on growth and yield. Field Crop Abst., 37(2-3):115.

[29] Abdel Malik, S.H.; Negm, M.A. and Bachata, M.A. (1976). Corn yield as affected by NPK fertilization calcareous soil. Agric. Res. Rev. (Egypt). 52(4):57-61.

[30] Ali , F.A (1996) .Maize Programme, Annual Report Agricultural Research Corporation .

[31] Arab Organization For Agricultural Development (2006) .Study For Corn Production. Khrtoum.Sudan ( Arab Issue).

[32] Okajima, H.; Taniyama, I.; Kawakami, R.And Fujitsu, I. (1983). The Nitrogen Balance In Soils Growing Corn. Field Crop Abst., 37 (7):561- Abst 5211.

[33] Affholder, F.,E. Scopel, J.Maderia, and A. capillion.2001 diagnosis of the productivity gap using a crop model. Methodology and case study of small-scale maize production in central Brazil.(Accepted in Agronomie).

[34] Gardner, C.A.C.; Bax, P.L.; Bailey, D.J.; Cavulieri, A.J.; Clausen (1990). Response of corn hybrids to nitrogen fertilizer. 3(1):39-43 [En, 13ref] Pioneer Hi-Bred International Mo 6-4633, USA.

[35] Hanway, J. 1971 .How A Corn Plant Develops. State University of Science And Technology-Cooperative 
Extension Services. Ameslowa-Special Report, No.48.15.Pp.

[36] Berzensy,Z. P.Bonis.T.Arendas And D.Q.Lap-1995. Investigation About The Effects of Some Factors Influencing Efficacy of Post-emergence Weed Control In Maize (Zea mays L).Proceeding $9^{\text {th }}$ Ewrs (European Weed Research Society ) Symposium, Budapest, 257-264

[37] Delpine.A.Andg Covareli. 1999 Critical Period Of Weed Control Competition In Maize. In Proceedings Of The 11thewrs (European Weed Research Society Symposium. Basel, Switzerland ,68.Detlefsen. D;R.D Lirick,
[38] Adediran, J.A.; Banjoko, V.A. (1995). Response of maize to $\mathrm{N}, \mathrm{P}$ and $\mathrm{K}$ fertilizers in the Savannah zone of Nigeria, Commun. Soil Sci. Plant Anal., 26:593-606.

[39] FPDD, Fertilizer Procurement and Distribution Division (1990). A review of soil and fertilization use research in Nigeria. In: Litera Review on Soil Fertility Investigations in Nigeria (Eds Enwezor et al.) Produced in five volumes by the Fertilizer Procurement and Distribution Division (FPDD), Federal Ministry of Agricultural Resources, Lagos, Nigeria, 281PP. 